\title{
Interest Rate Pass-Through and Monetary Transmission: Evidence from Individual Financial Institutions' Retail Rates
}

\author{
By Boris Hofmann and Paul Mizen ${ }^{1}$
}

Final version received 21 May 2001.

\begin{abstract}
Official interest rate changes should influence short rates on money market instruments and retail products, such as deposit accounts and mortgages, but complete pass-through is often taken for granted. This paper provides a theoretical and econometric framework for assessing the evidence for this assumption using seventeen years of monthly data for rates on thirteen deposit and mortgage products offered by individual UK financial institutions. The methodology allows for asymmetries and non-linearities in adjustment and the results show that the speed of adjustment in retail rates depends on whether the perceived 'gap' between retail and base rates is widening or narrowing.
\end{abstract}

\section{INTRODUCTION}

In recent years, virtually all central banks in the industrialised countries have conducted monetary policy through market-orientated instruments designed to influence short-term interest rates (Borio, 1997). By ensuring that the money markets are always short of cash on a daily basis, central banks reserve the right to supply the shortage at a price of their own choosing (the official rate). There is a presumption that these official rate changes will feed through to influence the array of short term money market rates and the rates set by banks and building societies on retail products, such as deposit accounts and mortgages. For monetary control that is influential over the future path of spending and inflation, it is desirable that - changes in the supply-side of financial intermediaries aside - market and retail rates should follow official rates closely. Goodfriend (1991) has described the official rate as a lever that operates through short rates on longer rates, which have greater influence over aggregate demand. If monetary policy actions are to be influential, official rate changes should be completely 'passed through' to market and retail rates over a reasonably short horizon. In practice official rates changes may not be fully and instantaneously passed through to retail rates. Differentials may persist for a time if banks and building societies adjust their margins, or if they face nonnegligible costs of adjustment to rates.

The issue of pass-through has received attention in the industrial organisation literature in order to explain how costs are passed through to prices in oligopolistic markets. In particular, the question of how costs are transmitted internationally has engaged theorists and empirical researchers in international economics. Exchange rate pass-through has been given theoretical foundations by Dornbusch (1987), Krugman (1987) and Dixit (1989) in order to motivate both static and dynamic models of pass-through behaviour. Empirical applications on imported goods have been provided by Mann 
(1986), Froot and Klemperer (1989), Marston (1990), Athukorala and Menon (1994), and Feenstra, Gagnon and Knetter (1996) for products ranging from oil and automobiles to microwave ovens and electronic goods. Often a range of products is considered for a specific exporting country or destination market. Our interest in this paper is the pass-through of official rates to individual financial institutions' retail rates. This parallels the industrial organisation literature in that the base rate is effectively the determinant of a financial institution's cost of funds, and the retail rate is the price of its product. The analysis of pass-through in retail interest rates is therefore a specific case of cost pass-through which has implications for the transmission of monetary policy.

A literature on this aspect of pass-through already exists. Two papers by Paisley (1994) and Heffernan (1997) use conventional linear methods to investigate these relationships but these studies find mixed evidence for passthrough. Heffernan's study finds complete pass-through for repayment mortgages and incomplete pass-through for savings and chequing accounts in the long run for UK banks and building societies; Paisley does not find complete pass-through in mortgage rates for UK building societies. The evidence taken from cointegration analysis and linear error correction models assumes that the speed of adjustment is the same under all circumstances. We investigate the possibility that there are asymmetries and non-linearities in the adjustment process. Both Hannan and Berger (1991) and Mester and Saunders (1995) have allowed for asymmetries in their models, but they use US deposit and prime rate changes, rather than UK data; and assume that rate changes are discrete. Their models attempt to determine the probabilities associated with upward, downward or no rate changes using a multinomial logit model. ${ }^{2}$

We consider the retail rate setting process as potentially asymmetric and implement a non-linear switching model that has some similarities with the approach taken by Neumark and Sharpe (1992) and Frost and Bowden (1999) who use a switching model of partial adjustment for US deposit rates. Our model allows for switching according to an indicator function that can determine the influence of the sign of, but also the size and the change in, the difference between the current retail rate and its long-run equilibrium, or by exogenous variables that provide information on its expected future path. The switching variable is then used to create a non-linear error correction model to capture asymmetries and non-linearities in the adjustment of deposit and mortgage rates, using methods introduced by Granger and Lee (1989) and further developed by Scholnick (1996) and Frost and Bowden (1999). These papers have used two-step estimators. We utilise both a two-step and a onestep estimator of linear and non-linear adjustment models of official rate passthrough to retail rates in order to allow for potential biases in the estimates. ${ }^{3}$ We make use of detailed monthly data on retail rates set by individual UK banks and building societies provided by the Bank of England over the period 1985-2001.

The paper is organised as follows. The next section explains the theoretical model, Section III sets out the econometric methodology we employ, Section IV describes the data and Section V reports the results. Section VI concludes. 


\section{THEORETICAL MODEL}

It is typically assumed in theoretical models that deposit taking financial institutions have some degree of monopoly power in price setting, and they are normally represented in theoretical settings by monopolistic competitors facing linear demand functions and quadratic costs. But monopolistic competition may not be sufficient to generate the discontinuous adjustment that we observe in retail rates. ${ }^{4}$ The costs of adjustment must imply that the profit function flattens off to discourage instantaneous adjustment in response to shocks. For a departure from continuous adjustment to retail rates (instantaneous and complete pass-through) we require costs to be associated with adjustment of rates. Costs may arise due to the search for information, Blanchard and Fischer (1989); menu costs of adjusting prices, Akerlof and Yellen (1985), Ball and Romer (1989), Mankiw (1985), Ball and Mankiw (1994); or non-pecuniary costs of lost custom after adjustment to rates, Rotemberg (1992). ${ }^{5}$

When these costs exist, rate setters have an incentive to avoid passing through minor changes to official rates, to anticipate the direction of a sequence of small changes to official rates accumulating them in a single retail rate change, and to anticipate turning points. When the profit function is flat, there is little incentive to adjust rates to small changes in official rates. Only when it is anticipated that there will be a succession of rate changes in the same direction will banks and building societies have an incentive to adjust rates. These could then be introduced in a cost minimising way by pre-empting the full increase or by catching-up with official rates after the event. By foreseeing a turning point, the costs of reversals could be avoided (by not following the curve all the way to the top and the bottom of the cycle), but rather catching the rates on the way back up or down. Financial institutions could reduce costs by smoothing official rates: this would involve forward-looking dynamic behaviour to anticipate the future path of official rates.

Our thinking on this point leads us to build a simple model as a variant of the asymmetric adjustment framework of Ball and Mankiw (1994). In their model, firms have a desired price made up of the sum of the general price level and the desired relative price. Assuming a steady inflation rate, firms set prices for two periods with the option to reset in the intervening period at a cost (the menu cost). Trend inflation is known, but relative prices are subject to shocks and these may trigger adjustment. Ball and Mankiw show that the range of shocks for which adjustment does not occur is asymmetric and the lower bound is larger than the upper bound because trend inflation provides some of the adjustment necessary to counter the negative shock.

We consider a similar conceptual model in which the banking firm may adjust its retail rates every even dated period, and can choose to make an additional change in an odd dated period at a fixed cost, $C$. At the beginning of each even period the monetary policy committee (MPC) decides on base rates. After observing this decision the financial institution sets retail rates for the current and the following period. If we assume that the loss function of the financial institution is quadratic in the difference of retail rates from their desired levels, then the retail rate set at the beginning of every even period for 
the next two periods ( 0 and 1$)$ is given by:

$$
r_{0}^{*}=\frac{b_{0}+E b_{1}}{2},
$$

where $b_{0}$ is the current (even period) base rate and $E_{0} b_{1}$ is the following expected base rate. ${ }^{6}$ This determines the ex ante optimal retail rate.

After setting retail rates a shock, say an unexpected innovation to the base rate, can cause the desired retail rate for the next period to change (note that retail rates would be equal to the base rate if they could be adjusted continuously and without any cost):

$$
b_{1}=E b_{1}+\varepsilon
$$

where $\varepsilon$ is a shock which is normally distributed with zero mean and constant variance. The financial institution can now decide to adjust rates, re-setting them to the optimal level for the next two periods:

$$
r_{1}^{*}=\frac{b_{1}+E b_{2}}{2}
$$

There is only an incentive for the financial institution to adjust its retail rate if the loss of not adjusting is higher than the menu cost:

$$
E_{1} \sum_{i=0}^{1}\left[\left(r_{0}^{*}-b_{1+i}\right)^{2}-\left(r_{1}^{*}-b_{1+i}\right)^{2}\right]=2\left(r_{0}^{*}-r_{1}^{*}\right)^{2}>C
$$

This can be rearranged to yield:

$$
\left[\left(r_{0}^{*}-b_{1}\right)-\frac{E_{1} b_{2}-b_{1}}{2}\right]^{2}>\frac{C}{2}
$$

The first term is the deviation from long-run equilibrium, the second term represents the expected change in the base rate. The financial institution will not adjust iff:

$$
\left(r_{0}^{*}-b_{1}\right) \in\left[-\sqrt{\frac{C}{2}}+\frac{E_{1} b_{2}-b_{1}}{2}, \sqrt{\frac{C}{2}}+\frac{E_{1} b_{2}-b_{1}}{2}\right] .
$$

This condition generates two hypotheses. First, adjustment is predicted to be asymmetric. We expect to find that the response to a shock of a given magnitude will depend on whether the shock is positive or negative. This hypothesis indicates that, for a given positive disequilibrium, adjustment is more likely if base rates are expected to fall, and for a given negative disequilibrium, adjustment is more likely if base rates are expected to rise. Second, adjustment is predicted to be non-linear and related to forwardlooking variables that identify the future direction of rates. Adjustment will therefore be faster if the expected differential between the current base rate and its future value widens, and slower if the expected differential narrows. The role of forward-looking variables introduces expectations, the appropriate horizon over which the differential might be calculated, and other indicators of the future path of rates.

As central banks have tended to make many small steps in place of few large ones in recent years (cf. Goodhart (1996) and Sack (1998)) base rates have 
been smoothed and therefore autocorrelated. In view of this, financial institutions - for whom the menu costs of changing rates are considerably higher in pecuniary and non-pecuniary terms than for the central bank - have formed expectations about the future trend in base rates when official rates are expected to follow a sequence of steps. If the base rates are autocorrelated and the differential is expected to widen further, they may pass through the total anticipated base rate change into retail rates in full. Whether this would tend to cause retail rates to anticipate official rates changes (so that retail rates lie ahead of the curve) or to follow them (so that retail rates lie behind the curve) will be a feature associated with the type of institution and the product in question.

As far as pass through is concerned, financial institutions have two options in the face of a shock: (i) they can take a lower margin in the odd period; or (ii) they can incur a one-off menu cost to increase retail rates, thereby narrowing the expected differential in the odd period. Under option one, pass through of base rate changes to retail rates is zero percent; under option two it is one hundred percent. The possibility of intermediate levels of pass through occurs because the decision to wait/respond is re-assessed every period in the light of expectations about the future path of the base rates. A sequence of decisions to wait, followed by one-hundred percent pass through in the $k$ th period, would yield a rate of $(100 / k) \%$ pass through.

Our model has both state-dependent and time-dependent features that can take into account endogenous and exogenous factors influencing the expected path of future base rates. ${ }^{7}$ Models of this kind should map a dynamic response to shocks in the face of these adjustment costs and the econometric specification that we use is a switching model, (cf. Frost and Bowden, 1999) as the next section explains.

\section{ECONOMETRIC IMPLEMENTATION}

At the outset we take advantage of the fact that we aim to understand the longrun relationship between only two variables, a retail rate $\left(y_{t}\right)$ and the (official) base rate $\left(x_{t}\right)$, both of which were found to be non-stationary using standard tests. ${ }^{8}$ There can be at most one cointegrating relationship between these two variables. If $x_{t}$ is weakly exogenous, which is an empirical matter to be confirmed in the paper, then we can write the modelling framework as:

$$
\begin{aligned}
& \phi(L) y_{t}=\mu+\theta(L) x_{t}+\varepsilon_{t} \\
& x_{t}=x_{t-1}+\eta_{t} \\
& \phi(L)=1-\sum_{i=1}^{\infty} \phi_{i} L^{i}, \theta(L)=1-\sum_{i=1}^{\infty} \theta_{i} L^{i}
\end{aligned}
$$

Here $\phi(L)$ and $\theta(L)$ are lag polynomials, $y_{t}$ is the dependent variable (the retail rate series), and $x_{t}$ is the base rate, which is a random walk; $\mu$ is an intercept term. The variables $\varepsilon_{t}$ and $\eta_{t}$ are random errors. This model can be written as

$$
y_{t}=\alpha+\beta^{\prime} x_{t}+\left[\frac{\phi(1)-\phi(L)}{\phi(1)(1-L)}\right] \Delta x_{t}+\left[\frac{\theta(1)-\theta(L)}{\theta(1)(1-L)}\right] \Delta y_{t}+\frac{\varepsilon_{t}}{\phi(1)}
$$

(C) The London School of Economics and Political Science 2004 
where $\alpha=\mu / \phi(1)$ and $\beta=\theta(1) / \phi(1)$. Equation (8) can be reformulated in error correction model (ECM) form as:

$$
\Phi(L) \Delta y_{t}=\mu+\Theta(L) \Delta x_{t}-\gamma\left[y_{t-k}-\beta x_{t-k}\right]+\varepsilon_{t}
$$

where $\gamma=\phi(1), \Phi(L)=\left[\frac{\phi(L)-\phi(1) L^{k}}{(1-L)}\right]$ and $\Theta(L)=\left[\frac{\theta(L)-\theta(1) L^{k}}{(1-L)}\right]$.

From this model we could estimate the average margin over base, $\alpha$, the rate of pass through in response to a base rate change, $\beta$, and the speed of adjustment to equilibrium, $\gamma$, i.e. the loading coefficient.

Given that the adjustment process in equation (9) is linear, it cannot take into account the possibility that adjustment is variable. Yet we have already shown that adjustment might very well be non-linear due to the menu-cost argument offered by Ball and Mankiw (1994). Then the adjustment might be increased in response to some endogenous driver (such as the sign, size or change in the deviation from base) or an exogenous driver creating a non-linear adjustment process.

The empirical literature has recently shown an increasing interest in nonlinear time series models to explain the adjustment of retail rates to policy controlled rates. ${ }^{9}$ Scholnick (1996) allows the error correction model to reflect the asymmetry of adjustment based on the sign of the differential between official rates and deposit (lending) rates in Malaysia and Singapore. Enders and Granger (1998) use a heaviside indicator to allow for sign-based asymmetries in a threshold autoregressive (TAR) model and a momentumTAR model to allow for asymmetric responses to changes in the differential. ${ }^{10}$ Frost and Bowden (1999) summarise these alternatives as sign, size and path based non-linearities, but extend the analysis by considering endogenous drivers, i.e. the differential between the base rate and the retail rate or the error correction, and exogenous drivers, such as the lagged change in the base rate.

We can address some of the non-linearities in the adjustment process by allowing the adjustment to be dependent on endogenous drivers such as the sign, size or path of the disequilibrium between the retail rate and the base rate. If we define this disequilibrium, $u_{t-1}$ to be the deviation from long-run equilibrium in the previous period, $y_{t-1}-\beta x_{t-1}$ then we can consider the response of the adjustment process to the 'gap' as measured by the cointegration residual. In particular, suppose we distinguish between positive and negative gaps so that $u_{t-1}^{+}$and $u_{t-1}^{-}$indicate whether the deviation was above or below zero, defined by the product of $u_{t-1.1} 1^{+}\left(u_{t}\right)$ and $u_{t-1} .1^{-}\left(u_{t}\right)$, respectively. The indicator function implies $1^{+}\left(u_{t}\right)=1 \Leftrightarrow u_{t}>0$ zero otherwise and $1^{-}\left(u_{t}\right)=1 \Leftrightarrow u_{t}>0$ zero otherwise. With this model it is possible to analyse non-linearities in the adjustment process and its possible causes. Nonlinear adjustment could be the result of different adjustment speeds for residuals above and below zero. Taking $u_{t-1}^{+}=u_{t-1}$ if retail rates were above long-run equilibrium in period $t-1$ (i.e. $u_{t-1}>0$ ), and 0 otherwise, and $u_{t-1}^{-}=$ $u_{t-1}$ if they were below (i.e. $u_{t-1}<0$ ), and 0 otherwise. The model then takes the form: $\Phi(L) \Delta y_{t}=\gamma_{1} u_{t-1}+\gamma_{2} u_{t-1}^{+}+\gamma_{3} u_{t-1}^{-}+\Theta(L) \Delta x_{t}+\varepsilon_{t}$, which can be written in an identifiable form (using $u_{t-1}=u_{t-1}^{+}+u_{t-1}^{-}$):

$$
\Phi(L) \Delta y_{t}=\left(\gamma_{1}+\gamma_{2}\right) u_{t-1}^{+}+\left(\gamma_{1}+\gamma_{3}\right) u_{t-1}^{-}+\Theta(L) \Delta x_{t}+\varepsilon_{t}
$$

we can test asymmetry by attempting to reject the null that $\gamma_{1}+\gamma_{2}=\gamma_{1}+\gamma_{3}$.

(C) The London School of Economics and Political Science 2004 
If we take $d_{t}$ as the driver of the nonlinearity then $d_{t}^{+}$and $d_{t}^{-}$represent qualitative differences in the realisation of the driver and these are derived using an indicator function based on the sign of $d_{t}$. The driving process above assumes the values $d_{t}^{+}=1$ and $d_{t}^{-}=0$, but we need not treat $d_{t}$ as a simple sign-based indicator. It could be a function of the disequilibrium terms $u_{t-1}^{+}$ and $u_{t-1}^{-}$or changes in these terms $\Delta u_{t-1}^{+}$and $\Delta u_{t-1}^{-}$so as to offer more complex endogenous driving processes in the model:

$$
\begin{aligned}
\Phi(L) \Delta y_{t}= & \gamma_{1} u_{t-1}+\gamma_{2} u_{t-1}^{+} d_{t}^{+}+\gamma_{3} u_{t-1}^{-} d_{t}^{+} \\
& +\gamma_{4} u_{t-1}^{+} d_{t}^{-}+\gamma_{5} u_{t-1}^{-} d_{t}^{-}+\Theta(L) \Delta x_{t}+\varepsilon_{t} .
\end{aligned}
$$

Alternatively, we may wish to explain asymmetry with exogenous drivers, that is states of the world that are not summarised by the deviation from equilibrium $u_{t-1}$. There can be many different types of process but these could include the size of the base rate change, for example, so that the driver $d_{t}$ is then defined as the change in the base rate. Now $d_{t}^{+}=d_{t}$ if $d_{t}>0$, and 0 otherwise, and $d_{t}^{-}=d_{t}$ if $d_{t}<0$, and 0 otherwise. So $\gamma_{1}+\gamma_{2}$ would give the speed of adjustment if deviation from equilibrium was positive and base rates were rising, and $\gamma_{1}+\gamma_{3}$ would measure the speed of adjustment if deviation from equilibrium was negative and base rates were rising, and so on. The basic model remains (11) but the driving process changes from an endogenous to an exogenous process.

The issue in this paper is to determine the extent to which changes to the retail rates follow changes in base rates and to determine how fast the adjustment process occurs. The next section reports the results from each of the estimated models (10) and (11) for individual retail rate series. These indicate the relationship between base rates and deposit rates and mortgage rates offered by different financial institutions (labelled $D E P_{i}$ and $M O R T_{i}$ where $i=1$ to 6 for deposits and $i=1$ to 7 for mortgages). We take each retail rate as our dependent variable and consider how much of the adjustment in the base rate is 'passed through' to the retail rate. The interpretation of the parameters is straightforward. The intercept, $\alpha$, determines the percentage point difference between the retail rate in question and the base rate, while the slope parameter, $\beta$, denotes the responsiveness of the retail rates to official rate changes. An estimated value of the slope parameter equal to one would indicate complete base rate pass-through in the long run; values below unity would indicate less than full base rate pass through. An estimated parameter value greater than one is a statistical possibility but it is difficult to interpret economically because it suggests that the retail rate more than passes through the official rate change i.e. it responds by more than the official rate change in the long run. Overshooting in the short term is a possibility that has a sensible economic interpretation, however, since rate setters may believe that more official rate changes are 'in-the-pipeline', especially if they believe central bankers smooth rate changes.

Of particular interest is the possibility of a non-linear response to disequilibria between retail and base rates. The error-correction approach outlined above enables us to test a wide variety of hypotheses discussed in the previous section that might reasonably cause asymmetries in base rate pass through. We use both a two-step procedure, where the first step estimates the 
long-run equilibrium, and the second step involves estimation of the non-linear error correction model using the residuals from the first step, and a one-step procedure. ${ }^{11}$ Theory can tell us so much about the likely adjustment processes, but empirical evidence will tell us which types of drivers introduce nonlinearities. We have priors that the expected change in base rates is likely to influence the path of retail rates, but we do not have any views about the likely asymmetries or non-linearities that may be present. Therefore we select from a set of endogenous drivers proposed by Frost and Bowden (1999) and a set of exogenous drivers that proxy the future (expected) change in the base rate.

\section{DATA}

In this paper all data are end-of-month and span the period 1985(1) - 2001(12). The base rate series is taken from official sources and is the average of the four major clearing banks' base rates, which moves closely with the official rate. Very occasionally more than one rate change occurs within one month and the monthly figure then records the total increase within the month. Retail rates are individual rates offered by anonymised financial institutions on 90-day deposit accounts for medium balances (below £10,000) and of standard variable rate mortgages. ${ }^{12}$ Data are quoted rates from a single tier product and do not represent the whole book for the clearing banks and building societies taken from published sources by the Monetary and Financial Statistics Division of the Bank of England. They do not reflect all the information on each product since there can be substantial competition in an array of nonprice inducements built into retail products offered by banks and building societies that may alter more frequently than the retail rate itself. ${ }^{13}$ Due to confidentiality restrictions we are not able to reveal the identity of the financial institutions in the data set. Official rate changes may be met by alterations to these non-price dimensions to the product as well as changes to retail rates and we may find that a switch from one to the other introduces non-linearities in base rate pass-through as a result. This warns us to be cautious about our interpretation of non-linearities, since the 'true' price involves both pecuniary and non-pecuniary aspects. Non-linear adjustment may imply that adjustment has occurred in the unmeasured non-price dimension to the product rather than the measured retail rate. Non-linearities detected in this paper refer simply to the extent that the pecuniary dimension to the price, i.e. the measured retail rate, responds to official rates, which can be informative about the extent to which providers may be concerned about 'money illusion' over the level of rates.

\section{EMPIRICAL RESULTS}

\section{(a) Cointegration and weak exogeneity}

Tables $1 \mathrm{a}$ and $1 \mathrm{~b}$ report the results of the Johansen cointegration tests. In the underlying VARs the constant was restricted to lie in the cointegration space, thus assuming that there is no deterministic trend in interest rates. The lag order was determined based on the Schwarz-Bayes information criterion and is reported in the first column. Centred impulse dummies had to be included in 


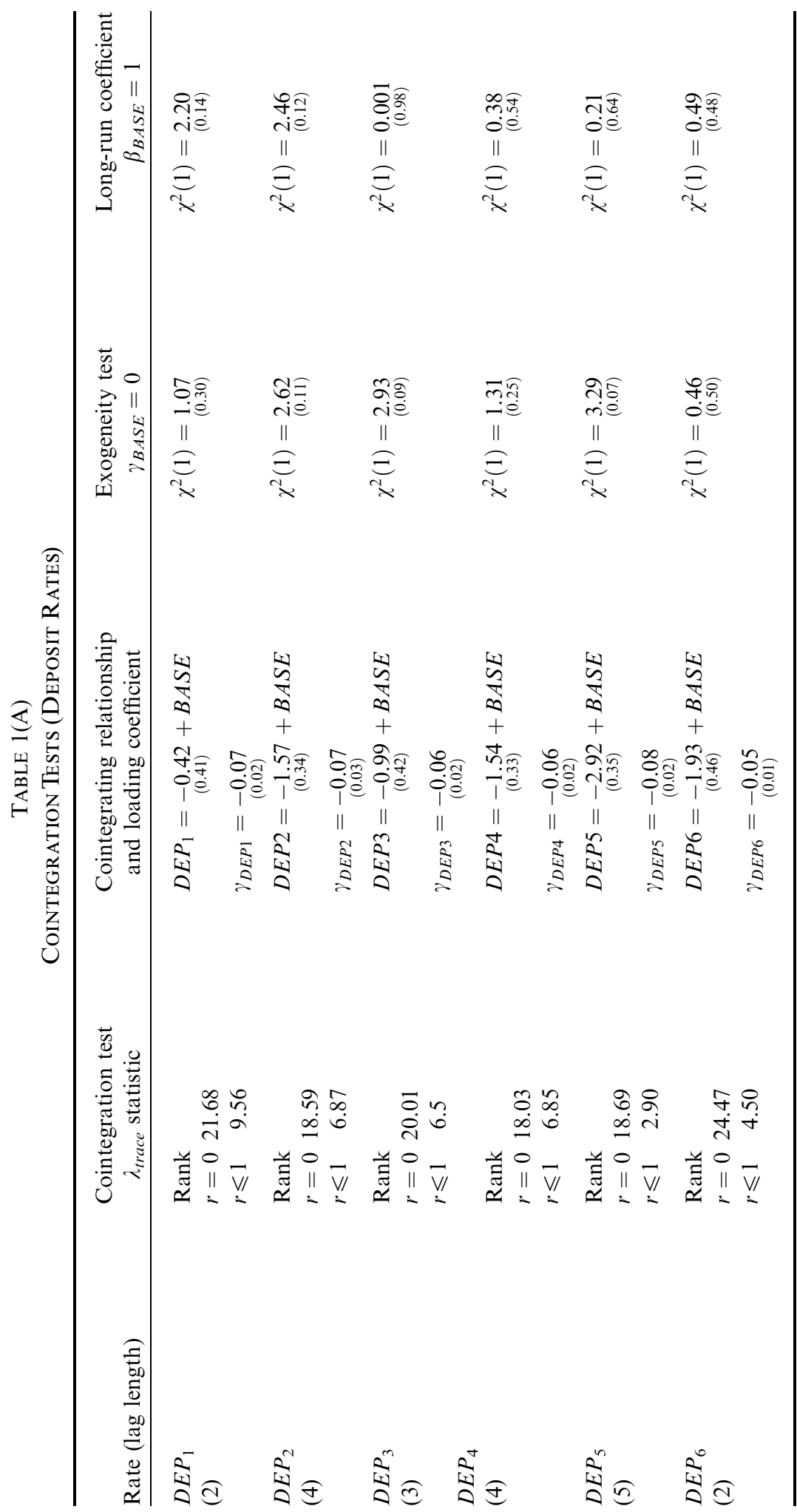




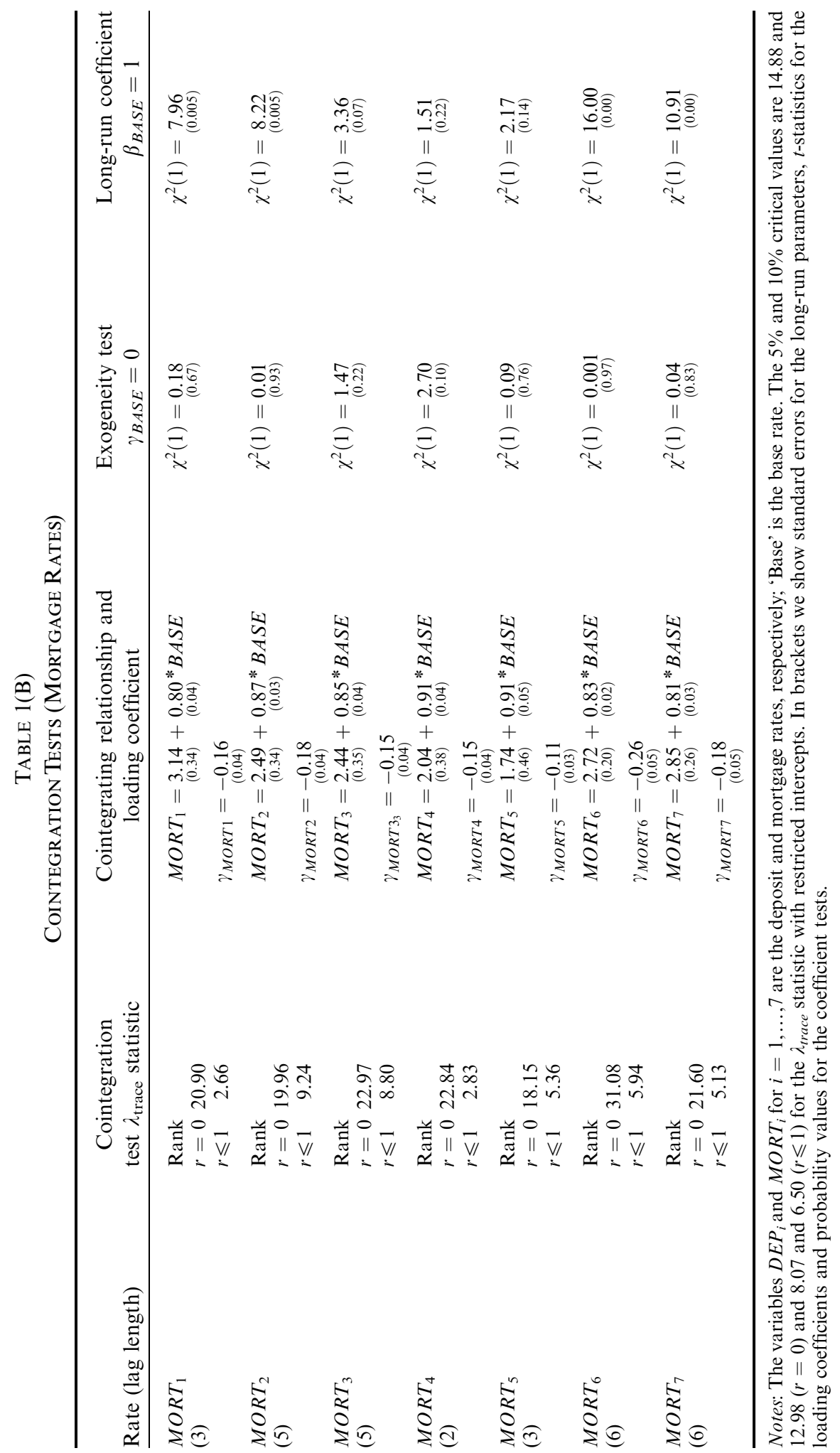


the VAR in order to eliminate heteroskedasticity. ${ }^{14}$ The first panel reports the results for six individual deposit rates and the second reports the results for seven individual mortgage rates. Taking deposit rates first, the test statistics imply that the null of no cointegration can be rejected in all cases (see column 2). The long run relationships are reported in column 3 and the associated adjustment coefficient, $\gamma$, is reported beneath it. The results show that for deposit rates the coefficient on the base rate can be restricted to equal one (unrestricted estimates were insignificantly different from unity). The adjustment coefficient for the deposit rates is small but significant in all cases. ${ }^{15}$ Previous empirical work on pass through has often taken it for granted that the base rate is exogenous, in column 4 we establish, using a test of the significance of the adjustment coefficient for the base rate, $\gamma_{\mathrm{BASE}}$, that we cannot reject the null that the adjustment coefficient is zero. In column 5 we test the joint hypothesis that the long-run pass-through is complete and we cannot reject the null. For mortgage rates the null of no cointegration can be rejected in all cases. The long run relationship is reported and the unrestricted coefficient is significantly different from unity for four out of six cases (this is confirmed in column 5). The adjustment coefficients for deposit rates are larger than for deposit rates and are significant, and the base rate is again exogenous.

\section{(b) Linear error correction models}

The linear error correction model is estimated in a single step using nonlinear least squares (NLLS) reported in Tables $2 \mathrm{a}$ and $2 \mathrm{~b}$. In order to get heteroskedasticity robust t-statistics we used Newey-West standard errors throughout. The consistency of the estimates of the margins compared to the previous estimates of the long run elasticities is encouraging and supportive of the theoretical model, which implies that financial institutions attempt to preserve their margins subject to menu costs. ${ }^{16}$

The adjustment speeds in the unrestricted error correction models imply between $5 \%$ and $9 \%$ adjustment to disequilibria per month in deposit rates and $15 \%-28 \%$ adjustment to disequilibria per month in mortgage rates. ${ }^{17}$ These adjustment speeds demonstrate that deposit rates and mortgage rates behave quite differently according to linear ECM models, but the speeds of adjustment increase somewhat in response to certain triggers of non-linear adjustment, as predicted by the theory. The diagnostic tests point to stable, linear ECMs over the sample period. ${ }^{18}$

\section{(c) Non-linear error correction models with endogenous drivers}

We now consider the responsiveness of retail rates when there are asymmetries and non-linearities due to endogenous and exogenous driving processes. All of our results refer to non-linearities in the adjustment process, $\gamma{ }^{19}$ Taking the endogenous drivers first, we report a model in which the adjustment is sign dependent, so that we use equation (11) where $d_{t}^{+}=1, d_{t}^{-}=0$. Alternative endogenous drivers such as state dependence and path dependence are not significant.

Tables $3 \mathrm{a}$ and $3 \mathrm{~b}$ report the model (a) where the first column is the estimated coefficient for the net combination of the symmetric and positive 
residual coefficients and the second column reports the equivalent for negative values. The absolute size of the coefficient indicates the responsiveness to positive (negative) disequilibrium. If the size is identical the model is symmetric. For deposit rates the point estimates of the coefficients imply that coefficients are different in size but a likelihood ratio test in column 3 cannot reject the null that the absolute value of the coefficients are equal on each of the positive and negative disequilibrium terms. Only for deposit rate six is there evidence that the deposit rate adjusts faster downwards when deposit rates are above their long-run level. This implies that sign is not a significant cause of non-linearity. We note that if the positive and negative values occur with equal frequency then we recover the average adjustment rate estimated under the linear model. For mortgage rates we obtain the same final conclusion that sign is not the driver of non-linearities, but our point estimates on positive and negative disequilibria are much closer to the same absolute value than they were for deposit rates.

The empirical literature on non-linear pass-through mainly focuses on differences between the upward and downward responsiveness of retail rates. If competition in the market for deposits (loans) is very competitive, financial institutions may be more reluctant to adjust deposit (loan) rates downwards (upwards) in order to avoid loss of customers. On the other hand, if the intensity of competition is rather low and financial institutions operate in a sellers' market, i.e. if customers are not able or not willing to move quickly to another service provider offering better conditions, financial institutions may be slower to adjust deposit (loan) rates downward (upward) in order to increase average profits over the interest rate cycle (Scholnick, 1996). Asymmetric retail rate setting may be reflected by asymmetric responses to changes in official rates or by non-linear error correction. We consider both possibilities.

Hannan and Berger (1993) and Mester and Saunders (1995) model US deposit and prime rate changes respectively using discrete dependent variable estimation techniques. Separating their samples into sub-samples, including only deposit/prime rate increases and decreases respectively, they investigated the presence of asymmetries in rate setting. Mester and Saunders (1995) find that changes in the exogenous variables generally triggered a larger probability of an upward response than a downward response in prime rates. Hannan and Berger (1991) find that deposit rates are significantly more rigid when the direction of the stimulus is upward. These studies have access to a sample of high frequency (daily) data for a large number of financial institutions. Unfortunately, for our data set the sample is measured at a much lower frequency (monthly), with many instances of no change, which makes the use of Logit analysis less reliable. Instead we make use of standard regression techniques following Heffernan (1997) and Borio and Fritz (1995). We test the non-linear response to base rate changes where we include an interaction dummy $\lambda \cdot D U M \cdot \Delta B A S E$ into a linear error correction model. The variable $D U M$ is equal to one when base rates are increasing and zero otherwise. Whether adjustment of retail rates is significantly faster or slower when base rate are increasing can then be assessed by testing whether the coefficient $\lambda$ is significantly larger or smaller than zero. Model (b) in Tables 3a and 3b reports the results for each institution's deposit 


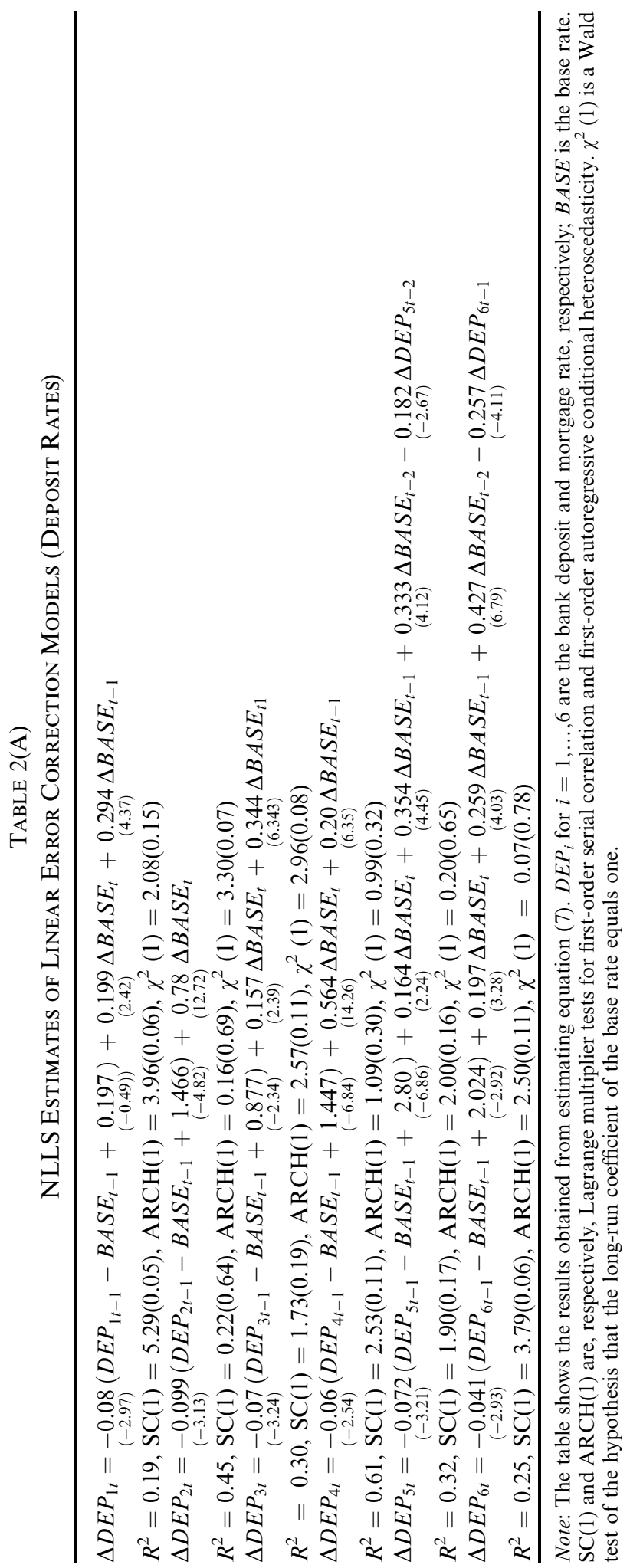




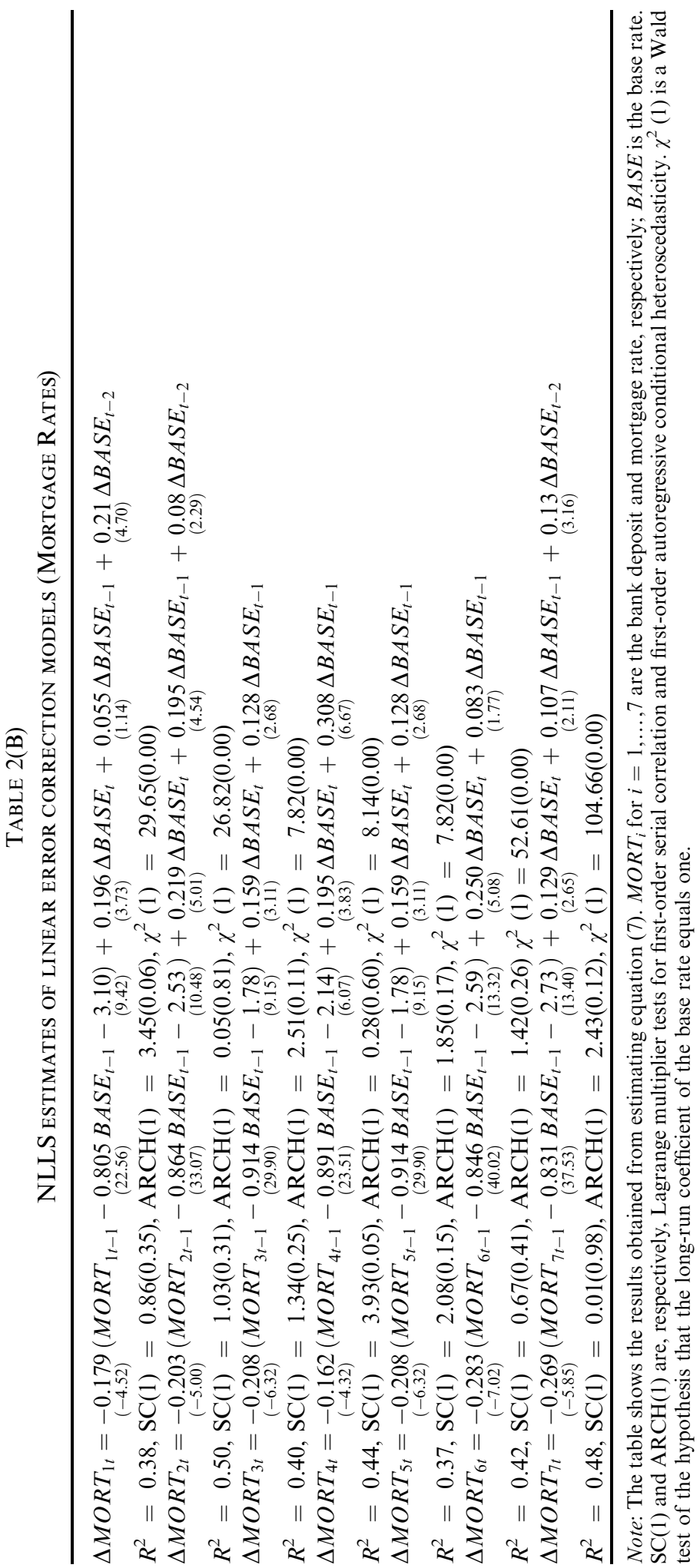


and mortgage rate giving the estimated $\lambda$ coefficient with the t-statistic in parentheses.

The evidence for asymmetric adjustment based on the sign of the change in base rates is not strong. Only for deposit rate two and four there is evidence that deposit rates are adjusted significantly more slowly when base rates are rising than when they are falling, and for mortgage rate two the adjustment is significantly faster when base rates are rising. The coefficient estimates are mostly insignificant. Our findings are therefore broadly in line with the findings of Heffernan (1997), who concludes that there is little evidence that there is a difference in the responsiveness of retail rates in times when base rates are rising compared to times when they are falling.

\section{(d) Non-linear error correction models with exogenous drivers}

The remaining results reported in Tables $4 \mathrm{a}$ and $4 \mathrm{~b}$ are for exogenous drivers. These imply that the process generating the non-linearity are exogenous factors to the model that help explain the future evolution of base rates. Our theoretical model implies that expected future changes to the base rate should be important determinants of the speed of equilibrium adjustment. We consider the actual change in base rates and a measure of the expected future change to base rates measured by yield spreads. The results we report are consistent with faster adjustment to widening gaps and slower adjustment to narrowing gaps as predicted by the theory.

TABLE 3(A)

Non-Linear ECMs: Endogenous Drivers (Deposit Rates)

\begin{tabular}{|c|c|c|c|c|c|}
\hline $\begin{array}{l}\text { (a) Sign } \\
\text { dependence }\end{array}$ & $\hat{\gamma}_{1}+\hat{\gamma}_{2} \hat{\gamma}_{1}+\hat{\gamma}_{3}$ & $\begin{array}{l}\text { LR test } \sim \chi \\
H_{0}: \gamma_{2}=\gamma_{3}\end{array}$ & $R^{2} \mathrm{~S}$ & $\mathrm{SC} \sim \chi^{2}(12)$ & $\mathrm{ARCH} \sim \chi^{2}(12)$ \\
\hline$D E P_{1}$ & $\begin{array}{c}-0.091-0.060 \\
(-3.11)(-1.37)\end{array}$ & $\begin{array}{c}0.40 \\
(0.53)\end{array}$ & 0.33 & $\begin{array}{c}3.77 \\
(0.05)\end{array}$ & $\begin{array}{c}3.41 \\
(0.06)\end{array}$ \\
\hline $\mathrm{DEP}_{2}$ & $\begin{array}{l}-0.111-0.072 \\
(-2.23)(-2.00)\end{array}$ & $\begin{array}{c}0.41 \\
(0.52)\end{array}$ & 0.45 & $\begin{array}{c}2.26 \\
(0.13)\end{array}$ & $\begin{array}{c}0.12 \\
(0.73)\end{array}$ \\
\hline $\mathrm{DEP}_{3}$ & $\begin{array}{r}-0.063-0.046 \\
(-2.49)(-1.26)\end{array}$ & $\begin{array}{c}0.16 \\
(0.69)\end{array}$ & 0.33 & $\begin{array}{c}3.76 \\
(0.06)\end{array}$ & $\begin{array}{c}6.75 \\
(0.87)\end{array}$ \\
\hline $\mathrm{DEP}_{4}$ & $\begin{array}{r}-0.064-0.056 \\
(-2.00)(-1.56)\end{array}$ & $\begin{array}{c}0.03 \\
(0.85)\end{array}$ & 0.61 & $\begin{array}{c}1.03 \\
(0.31)\end{array}$ & $\begin{array}{c}2.78 \\
(0.10)\end{array}$ \\
\hline $\mathrm{DEP}_{5}$ & $\begin{array}{ll}-0.07 & -0.072 \\
(-2.54) & (-1.73)\end{array}$ & $\begin{array}{c}0.01 \\
(0.97)\end{array}$ & 0.32 & $\begin{array}{c}1.59 \\
(0.21)\end{array}$ & $\begin{array}{l}1.63 \\
(0.20)\end{array}$ \\
\hline$D E P_{6}$ & $\begin{array}{rr}-0.09 & -0.002 \\
(-4.56) & (-0.08)\end{array}$ & $\begin{array}{l}8.00 \\
(0.005)\end{array}$ & 0.26 & $\begin{array}{c}3.76 \\
(0.06)\end{array}$ & $\begin{array}{l}1.65 \\
(0.20)\end{array}$ \\
\hline $\begin{array}{l}\text { (b) Further tests } \\
\text { for sign dependence }\end{array}$ & $t$-statistic & & & & \\
\hline$D E P_{1}$ & $0.03 \quad(0.20)$ & & & & \\
\hline $\mathrm{DEP}_{2}$ & $-0.27(-2.05)$ & & & & \\
\hline $\mathrm{DEP}_{3}$ & $-0.01(-0.08)$ & & & & \\
\hline $\mathrm{DEP}_{4}$ & $-0.29(-3.54)$ & & & & \\
\hline $\mathrm{DEP}_{5}$ & $-0.06(-0.39)$ & & & & \\
\hline $\mathrm{DEP}_{6}$ & $-0.12(-0.87)$ & & & & \\
\hline
\end{tabular}


TABLE 3(B)

Non-Linear ECMs: Endogenous Drivers (Mortgage Rates)

\begin{tabular}{|c|c|c|c|c|c|c|}
\hline $\begin{array}{l}\text { (a) Sign } \\
\text { dependence }\end{array}$ & $\hat{\gamma}_{1}+\hat{\gamma}_{2}$ & $\hat{\gamma}_{1}+\hat{\gamma}_{3}$ & $\begin{array}{l}\text { LR test } \sim \chi(1 \\
H_{0}=\gamma_{2}=\gamma\end{array}$ & $R^{2} \mathrm{SC}$ & $\mathrm{SC} \sim \chi^{2}(12)$ & $\mathrm{ARCH} \sim \chi^{2}(12)$ \\
\hline$M O R T_{1}$ & $\begin{array}{l}-0.178 \\
(-3.60)\end{array}$ & $\begin{array}{l}-0.176 \\
(-3.47)\end{array}$ & $\begin{array}{r}0.001 \\
(0.97)\end{array}$ & 0.38 & $\begin{array}{l}0.65 \\
(0.42)\end{array}$ & $\begin{array}{c}3.47 \\
(0.06)\end{array}$ \\
\hline $\mathrm{MORT}_{2}$ & $\begin{array}{l}-0.244 \\
(-4.83)\end{array}$ & $\begin{array}{l}-0.159 \\
(-3.18)\end{array}$ & $\begin{array}{l}1.99 \\
(0.15)\end{array}$ & 0.51 & $\begin{array}{c}0.94 \\
(0.33)\end{array}$ & $\begin{array}{c}0.005 \\
(0.94)\end{array}$ \\
\hline $\mathrm{MORT}_{3}$ & $\begin{array}{l}-0.29 \\
(-5.93)\end{array}$ & $\begin{array}{l}-0.234 \\
(-5.02)\end{array}$ & $\begin{array}{c}0.95 \\
(0.33)\end{array}$ & 0.40 & $\begin{array}{c}1.18 \\
(0.28)\end{array}$ & $\begin{array}{c}2.65 \\
(0.10)\end{array}$ \\
\hline $\mathrm{MORT}_{4}$ & $\begin{array}{l}-0.195 \\
(-3.99)\end{array}$ & $\begin{array}{l}-0.128 \\
(-2.57)\end{array}$ & $\begin{array}{l}1.04 \\
(0.31)\end{array}$ & 0.44 & $\begin{array}{c}3.99 \\
(0.05)\end{array}$ & $\begin{array}{c}0.23 \\
(0.63)\end{array}$ \\
\hline$M O R T_{5}$ & $\begin{array}{l}-0.20 \\
(-4.81)\end{array}$ & $\begin{array}{l}-0.214 \\
(-5.03)\end{array}$ & $\begin{array}{c}0.06 \\
(0.80)\end{array}$ & 0.37 & $\begin{array}{c}1.73 \\
(0.19)\end{array}$ & $\begin{array}{c}2.43 \\
(0.12)\end{array}$ \\
\hline $\mathrm{MORT}_{6}$ & $\begin{array}{l}-0.285 \\
(-5.35)\end{array}$ & $\begin{array}{l}-0.277 \\
(-5.57)\end{array}$ & $\begin{array}{c}0.01 \\
(0.91)\end{array}$ & 0.42 & $\begin{array}{c}0.03 \\
(0.87)\end{array}$ & $\begin{array}{l}1.74 \\
(0.19)\end{array}$ \\
\hline $\mathrm{MORT}_{7}$ & $\begin{array}{l}-0.267 \\
(-4.691)\end{array}$ & $\begin{array}{l}-0.263 \\
(-4.95)\end{array}$ & $\begin{array}{c}0.004 \\
(0.95)\end{array}$ & 0.48 & $\begin{array}{c}0.01 \\
(0.97)\end{array}$ & $\begin{array}{c}2.31 \\
(0.13)\end{array}$ \\
\hline \multicolumn{7}{|l|}{ (b) Further tests } \\
\hline $\begin{array}{l}\text { for sign dependence } \\
M O R T_{1}\end{array}$ & $\begin{array}{cc}\lambda & t \\
0.03\end{array}$ & $\begin{array}{c}t \text {-statistic } \\
\quad(0.27)\end{array}$ & & & & \\
\hline $\mathrm{MORT}_{2}$ & 0.14 & (1.68) & & & & \\
\hline $\mathrm{MORT}_{3}$ & -0.06 & $(-0.57)$ & & & & \\
\hline $\mathrm{MORT}_{4}$ & 0.02 & $(0.20)$ & & & & \\
\hline $\mathrm{MORT}_{5}$ & -0.04 & $(-0.41)$ & & & & \\
\hline $\mathrm{MORT}_{6}$ & -0.12 & $(-1.29)$ & & & & \\
\hline $\mathrm{MORT}_{7}$ & 0.05 & (1.48) & & & & \\
\hline
\end{tabular}

Notes: The variables $D E P_{i}$ and $M O R T_{i}$ are the deposit and mortgage rates for institutions $i . t$ statistics in parentheses are based on Newey-West standard errors. SC is a chi-squared test for serial correlation; $H$ is a chi-squared test for heteroscedasticity ( $p$ values are in brackets).

A. Perfect foresight. Model (c) takes the driver to be the actual change in the base rate, which assumes that the institutions have perfect foresight about base rate changes. We then split the change into increases and decreases and multiply each by the positive and negative disequilibrium term lagged one period, using equation (11). The first term is interpreted as the underlying adjustment to a disequilibrium if the model is symmetric. The second (third) term indicates the non-linearity when the disequilibrium is positive but the base rate is rising (falling) and therefore narrowing (widening) the gap. The fourth (fifth) term indicates the case for negative disequilibria with a base rate that is rising (falling) and therefore widening (narrowing) the gap. We would expect non-linearities to induce faster adjustment when there is a gap that is widening and this is what we find.

When there are widening gaps (columns 3 and 4) we expect any response to ensure faster adjustment. Faster adjustment speed is shown when the coefficient has a negative sign in column 3 and when it has a positive sign in column 4. For deposits, we find that there are five cases where the adjustment speed increases in columns 3 and 4, for the remainder there is no change to the adjustment speed. With mortgages there is a consistent negative sign in column 
3 and a positive sign in column 4 , so that all seven mortgage rates show signs of increasing adjustment speed. There are no cases for either deposits or mortgages where the adjustment speed slows down when the gap widens. The results imply that both deposit and mortgage rates tend to adjust more quickly when the rates are above or below their desired levels and base rates are changing to widen the gap.

In the case when the gap is narrowing (columns 2 and 5) we expect any response to allow adjustment to take place automatically or to slow adjustment down. For four out of six deposit rates there is no alteration to the speed of adjustment in either column 2 or 5 , but for $\mathrm{DEP}_{2}$ and $\mathrm{DEP}_{4}$ there is a negative sign in column 5, which slows adjustment down. For mortgages we find more evidence that the adjustment slows, with positive signs in column 2 and negative signs in column 5. There are three cases where the adjustment remains the same, however, but there are none where the adjustment speed increases when the gap narrows. These results show deposit and mortgage rates do not show a faster response when the gap narrows as a result of the direction of change in base rates.

B. Alternative measures of expected changes to base rates. In addition to the perfect foresight case we also consider the changes expected in the base rate. We consider market based information on expectations constructed from yield spreads. According to the expectations theory of the term structure, the yield spread (i.e. the spread of the $n$-period nominal interest rate over the base rate) provides a measure of expected changes in the inflation rate. Given that the central bank cares about inflation, expected changes in the inflation rate could be an indicator for expected changes in the base rate. Taking the reasoning offered by Mishkin (1990a, 1990b, 1991), yields on longer maturity assets will reflect expectations of future inflation in their rates and yield spreads will widen. ${ }^{20}$ This will be an indication that markets expect higher base rates in the future. $^{21}$ Thus measures of expected inflation can herald expected changes to base rates and could indicate that the gap between retail and base rates are likely to widen (narrow), which would then determine whether retail rates should adjust more quickly (slowly). ${ }^{22}$

We tried several yield spread measures with horizons from three months to one year ahead. Although we do not have priors about the most informative horizon for the yield spread we find in practice that the results reported in Tables $4 \mathrm{a}$ and $4 \mathrm{~b}$ for models (c)-(f) are remarkably consistent. The findings are also consistent with our previous result using the actual change in the base rate, indicating that - when the gap is narrowing, retail rates adjust marginally more slowly, and when the gap is widening, adjustment is more rapid. We expect to find positively signed coefficients in columns 2 and 4 and negatively signed coefficients in columns 3 and 5. Taking deposit rates first of all we find that models (c)-(f) show evidence of positive coefficients in columns 2 and 4 for yield spreads at horizons of 3, 6 and 12 months. The same models provide evidence for negative coefficients in columns 3 and 5 at the same horizons. All other coefficients are insignificant and none are incorrectly signed. For mortgages, the results are similarly aligned. There are only two contradictory signs among seventy-eight coefficient estimates, and all other significant 
TABLE 4(A)

Non-Linear ECMs: Exogenous Drivers (Deposit Rates)

\begin{tabular}{|c|c|c|c|c|c|c|c|c|}
\hline Gap & - & $\mathrm{N}$ & W & W & $\mathrm{N}$ & & & \\
\hline $\begin{array}{l}\text { (d) Change in } \\
\text { base rate }\end{array}$ & $\hat{\gamma}_{1}$ & $\hat{\gamma}_{2}$ & $\hat{\gamma}_{3}$ & $\hat{\gamma}_{4}$ & $\hat{\gamma}_{5}$ & $\mathrm{R}^{2}$ & $\mathrm{SC}(1)$ & $\mathrm{ARCH}(1)$ \\
\hline$D E P_{1}$ & $\begin{array}{c}-0.08 \\
(-2.97)\end{array}$ & n.s. & n.s. & n.s. & n.s. & 0.19 & $\begin{array}{c}5.29 \\
(0.62)\end{array}$ & $\begin{array}{c}3.96 \\
(0.06)\end{array}$ \\
\hline$D E P_{2}$ & $\begin{array}{l}-0.106 \\
(-2.99)\end{array}$ & n.s. & n.s. & $\begin{array}{r}0.434 \\
(2.33)\end{array}$ & $\begin{array}{l}-0.310 \\
(-2.52)\end{array}$ & 0.43 & $\begin{array}{c}0.61 \\
(0.43)\end{array}$ & $\begin{array}{c}0.09 \\
(0.76)\end{array}$ \\
\hline $\mathrm{DEP}_{3}$ & $\begin{array}{c}-0.064 \\
(-2.96)\end{array}$ & & $\begin{array}{r}-0.344 \\
(-2.17)\end{array}$ & n.s. & n.s. & 0.31 & $\begin{array}{c}1.86 \\
(0.17)\end{array}$ & $\begin{array}{c}0.36 \\
(0.55)\end{array}$ \\
\hline $\mathrm{DEP}_{4}$ & $\begin{array}{l}-0.064 \\
(-2.21)\end{array}$ & n.s. & n.s. & $\begin{array}{r}0.371 \\
(2.87)\end{array}$ & $\begin{array}{r}-0.479 \\
(-2.22)\end{array}$ & 0.56 & $\begin{array}{c}1.93 \\
(0.16)\end{array}$ & $\begin{array}{c}0.12 \\
(0.73)\end{array}$ \\
\hline$D E P_{5}$ & $\begin{array}{c}-0.072 \\
(-3.21)\end{array}$ & n.s. & n.s. & n.s. & n.s. & 0.32 & $\begin{array}{c}3.79 \\
(0.06)\end{array}$ & $\begin{array}{c}2.00 \\
(0.16)\end{array}$ \\
\hline$D_{E} P_{6}$ & $\begin{array}{r}-0.027 \\
(-1.48)\end{array}$ & n.s. & $\begin{array}{c}-0.481 \\
(2.16)\end{array}$ & $\begin{array}{c}0.132 \\
(1.79)\end{array}$ & $\begin{array}{r}-0.289 \\
(-1.85)\end{array}$ & 0.26 & $\begin{array}{c}3.89 \\
(0.06)\end{array}$ & $\begin{array}{c}0.37 \\
(0.54)\end{array}$ \\
\hline
\end{tabular}

(e) Expected change in base (3-month yield spread)

\begin{tabular}{|c|c|c|c|c|c|c|c|c|}
\hline$D E P_{1}$ & $\begin{array}{r}-0.153 \\
(-4.49)\end{array}$ & $\begin{array}{c}0.592 \\
(2.76)\end{array}$ & n.s. & n.s. & $\begin{array}{r}-0.972 \\
(-2.67)\end{array}$ & 0.23 & $\begin{array}{c}3.72 \\
(0.05)\end{array}$ & $\begin{array}{c}3.95 \\
(0.05)\end{array}$ \\
\hline $\mathrm{DEP}_{2}$ & $\begin{array}{r}-0.058 \\
(-1.84)\end{array}$ & n.s. & n.s. & $\begin{array}{c}0.84 \\
(2.25)\end{array}$ & n.s. & 0.46 & $\begin{array}{c}1.26 \\
(0.26)\end{array}$ & $\begin{array}{c}0.11 \\
(0.74)\end{array}$ \\
\hline$D E P_{3}$ & $\begin{array}{r}-0.089 \\
(-3.51)\end{array}$ & $\begin{array}{c}0.25 \\
(1.64)\end{array}$ & n.s. & n.s. & $\begin{array}{r}-0.769 \\
(-1.96)\end{array}$ & 0.34 & $\begin{array}{c}2.82 \\
(0.09)\end{array}$ & $\begin{array}{c}5.18 \\
(0.03)\end{array}$ \\
\hline $\mathrm{DEP}_{4}$ & $\begin{array}{c}-0.06 \\
(-2.54)\end{array}$ & n.s. & n.s. & n.s. & n.s. & 0.61 & $\begin{array}{c}2.53 \\
(0.11)\end{array}$ & $\begin{array}{c}1.09 \\
(0.30)\end{array}$ \\
\hline$D E P_{5}$ & $\begin{array}{l}-0.072 \\
(-3.21)\end{array}$ & n.s. & n.s. & n.s. & n.s. & 0.32 & $\begin{array}{c}1.90 \\
(0.17)\end{array}$ & $\begin{array}{c}2.00 \\
(0.16)\end{array}$ \\
\hline$F t$ & $\begin{array}{r}-0.041 \\
(-2.30)\end{array}$ & n.s. & n.s. & $\begin{array}{r}0.237 \\
(1.66)\end{array}$ & $\begin{array}{r}-0.272 \\
(-1.67)\end{array}$ & 0.39 & $\begin{array}{c}3.30 \\
(0.07)\end{array}$ & $\begin{array}{c}1.45 \\
(0.23)\end{array}$ \\
\hline
\end{tabular}

(f) Expected change in base (6-month yield spread)

$\begin{array}{lcccccccc}D E P_{1} & -0.039 & \text { n.s. } & \text { n.s. } & 0.305 & \text { n.s. } & 0.22 & 3.32 & 2.86 \\ & (-1.25) & & & (2.60) & \text { n.s. } & & (0.07) & (0.09) \\ D E P_{2} & -0.057 & \text { n.s. } & \text { n.s. } & 0.392 & \text { n.s. } & 0.46 & 1.70 & 0.11 \\ & (-1.81) & & & (2.30) & & & (0.19) & (0.74) \\ D E P_{3} & -0.075 & \text { n.s. } & \text { n.s. } & \text { n.s. } & -0.426 & 0.31 & 2.20 & 3.46 \\ & (-3.45) & & & & (-1.92) & & (0.14) & (0.06) \\ D E P_{4} & -0.06 & \text { n.s. } & \text { n.s. } & \text { n.s. } & \text { n.s. } & 0.61 & 2.53 & 1.09 \\ & (-2.54) & & & & & & (0.11) & (0.30) \\ D E P_{5} & -0.072 & \text { n.s. } & \text { n.s. } & \text { n.s. } & \text { n.s. } & 0.32 & 1.90 & 2.00 \\ & (-3.21) & & & & & & (0.17) & (0.16) \\ D E P_{6} & -0.024 & \text { n.s. } & \text { n.s. } & 0.231 & \text { n.s. } & 0.27 & 3.30 & 1.44 \\ & (-1.37) & & & (3.19) & & & (0.07) & (0.23)\end{array}$


TABLE 4(A) CONTINUED

\begin{tabular}{lccccccccc}
\hline Gap & - & $\mathrm{N}$ & $\mathrm{W}$ & $\mathrm{W}$ & $\mathrm{N}$ & & & \\
\hline (g) Expected & change in base $(12-m o n t h$ & yield spread) & & & & \\
$D E P_{1}$ & -0.047 & n.s. & n.s. & 0.181 & n.s. & 0.22 & 3.42 & 2.99 \\
& $(-1.52)$ & & & $(2.21)$ & & & $(0.06)$ & $(0.08)$ \\
$D E P_{2}$ & -0.060 & n.s. & n.s. & 0.240 & n.s. & 0.46 & 2.02 & 0.12 \\
& $(-1.88)$ & & & $(1.97)$ & & & $(0.15)$ & $(0.73)$ \\
$D E P_{3}$ & -0.074 & n.s. & n.s. & n.s. & n.s. & 0.415 & 19.05 & 8.38 \\
& $(-3.38)$ & & & & & & & $(0.09)$ & $(0.75)$ \\
$D E P_{4}$ & -0.060 & n.s. & n.s. & 0.153 & n.s. & 0.54 & 2.19 & 1.09 \\
& $(-2.04)$ & & & $(1.65)$ & & & $(0.14)$ & $(0.30)$ \\
$D E P_{5}$ & -0.072 & n.s. & n.s. & n.s. & n.s. & 0.32 & 1.90 & 2.00 \\
& $(-3.21)$ & & & & & & $(0.17)$ & $(0.16)$ \\
$D E P_{6}$ & -0.023 & n.s. & n.s. & 0.147 & n.s. & 0.26 & 3.13 & 1.23 \\
& $(-1.31)$ & & & $(2.85)$ & & & $(0.07)$ & $(0.27)$ \\
\hline
\end{tabular}

TABLE 4(B)

Non-Linear ECMs: Exogenous Drivers (Mortgage Rates)

\begin{tabular}{llllll}
\hline Gap & - & $\mathrm{N}$ & $\mathrm{W}$ & $\mathrm{W}$ & $\mathrm{N}$ \\
\hline
\end{tabular}

(d) Change in

\begin{tabular}{lcccccccc} 
base rate & $\hat{\gamma}_{1}$ & $\hat{\gamma}_{2}$ & $\hat{\gamma}_{3}$ & $\hat{\gamma}_{4}$ & $\hat{\gamma}_{5}$ & $R^{2}$ & $\mathrm{SC}(1)$ & $\mathrm{ARCH}(1)$ \\
\hline MORT $_{1}$ & -0.167 & 0.397 & -0.40 & 0.515 & -0.713 & 0.43 & 0.16 & 0.43 \\
& $(-4.13)$ & $(1.73)$ & $(-3.66)$ & $(2.93)$ & $(-2.91)$ & & $(0.65)$ & $(0.52)$ \\
MORT $_{2}$ & -0.169 & n.s. & -0.672 & 0.292 & -0.412 & 0.55 & 1.32 & 0.04 \\
& $(-4.07)$ & & $(-4.30)$ & $(2.20)$ & $(-1.91)$ & & $(0.25)$ & $(0.84)$ \\
MORT $_{3}$ & -0.259 & n.s. & -0.249 & 0.264 & -0.379 & 0.42 & 0.09 & 0.21 \\
& $(-5.91)$ & & $(-2.34)$ & $(1.77)$ & $(-1.96)$ & & $(0.76)$ & $(0.64)$ \\
MORT $_{4}$ & -0.101 & n.s. & -0.776 & 0.584 & n.s. & 0.49 & 3.01 & 0.26 \\
& $(-2.56)$ & & $(-3.83)$ & $(3.15)$ & & & $(0.08)$ & $(0.60)$ \\
MORT $_{5}$ & -0.145 & 0.226 & -0.293 & 0.327 & -0.422 & 0.43 & 4.04 & 1.48 \\
& $(-4.05)$ & $(1.97)$ & $(-2.66)$ & $(2.34)$ & $(-2.06)$ & & $(0.05)$ & $(0.22)$ \\
MORT $_{6}$ & -0.30 & n.s. & -0.196 & n.s. & -0.443 & 0.45 & 0.001 & 3.55 \\
& $(-6.84)$ & & $(-2.29)$ & & $(-2.32)$ & & $(0.98)$ & $(0.06)$ \\
MORT $_{7}$ & -0.266 & 0.442 & -0.242 & 0.226 & -0.59 & 0.51 & 2.72 & 4.35 \\
& $(-5.63)$ & $(2.03)$ & $(-2.62)$ & $(1.69)$ & $(-2.54)$ & & $(0.09)$ & $(0.04)$
\end{tabular}

(e) Expected change in base (3-month yield spread)

\begin{tabular}{|c|c|c|c|c|c|c|c|c|}
\hline$M O R T_{1}$ & $\begin{array}{l}-0.183 \\
(-4.10)\end{array}$ & n.s. & $\begin{array}{l}-0.457 \\
(-1.66)\end{array}$ & n.s. & $\begin{array}{l}-1.375 \\
(-2.66)\end{array}$ & 0.41 & $\begin{array}{l}1.39 \\
(0.24)\end{array}$ & $\begin{array}{l}6.47 \\
(0.02)\end{array}$ \\
\hline $\mathrm{MORT}_{2}$ & $\begin{array}{c}-0.17 \\
(-4.06)\end{array}$ & n.s. & n.s. & $\begin{array}{c}0.642 \\
(2.42)\end{array}$ & n.s. & 0.52 & $\begin{array}{c}0.63 \\
(0.42)\end{array}$ & $\begin{array}{c}0.02 \\
(0.89)\end{array}$ \\
\hline $\mathrm{MORT}_{3}$ & $\begin{array}{r}-0.313 \\
(-7.93)\end{array}$ & n.s. & n.s. & n.s. & $\begin{array}{c}-1.594 \\
(-3.29)\end{array}$ & 0.43 & $\begin{array}{l}1.91 \\
(0.16)\end{array}$ & $\begin{array}{l}1.07 \\
(0.30)\end{array}$ \\
\hline $\mathrm{MORT}_{4}$ & $\begin{array}{r}-0.101 \\
(-2.39)\end{array}$ & n.s. & $\begin{array}{r}-0.724 \\
(-2.34)\end{array}$ & $\begin{array}{c}0.766 \\
(2.29)\end{array}$ & n.s. & 0.46 & $\begin{array}{l}4.05 \\
(0.05)\end{array}$ & $\begin{array}{l}0.27 \\
(0.60)\end{array}$ \\
\hline $\mathrm{MORT}_{5}$ & $\begin{array}{c}-0.234 \\
(-6.91)\end{array}$ & n.s. & n.s. & n.s. & $\begin{array}{r}-1.032 \\
(-2.28)\end{array}$ & 0.38 & $\begin{array}{c}2.01 \\
(0.16)\end{array}$ & $\begin{array}{c}0.86 \\
(0.35)\end{array}$ \\
\hline$M O R T_{6}$ & $\begin{array}{r}-0.317 \\
(-7.52)\end{array}$ & n.s. & n.s. & n.s. & $\begin{array}{r}-1.425 \\
(-2.31)\end{array}$ & 0.43 & $\begin{array}{c}0.26 \\
(0.61)\end{array}$ & $\begin{array}{c}3.21 \\
(0.07)\end{array}$ \\
\hline $\mathrm{MORT}_{7}$ & $\begin{array}{r}-0.287 \\
(-6.30)\end{array}$ & n.s. & n.s. & n.s. & $\begin{array}{r}-1.507 \\
(-2.54)\end{array}$ & 0.50 & $\begin{array}{c}2.64 \\
(0.10)\end{array}$ & $\begin{array}{c}2.13 \\
(0.13)\end{array}$ \\
\hline
\end{tabular}

(C) The London School of Economics and Political Science 2004 
TABLE 4(B) CONTINUED

\begin{tabular}{|c|c|c|c|c|c|c|c|c|}
\hline Gap & - & & $\mathrm{W}$ & $\mathrm{W}$ & $\mathrm{N}$ & & & \\
\hline \multicolumn{9}{|c|}{ (f) Expected change in base (6-month yield spread) } \\
\hline$M O R T_{1}$ & $\begin{array}{r}-0.221 \\
(-4.93)\end{array}$ & $\begin{array}{c}0.302 \\
(1.76)\end{array}$ & n.s. & n.s. & $\begin{array}{l}-0.257 \\
(-2.00)\end{array}$ & 0.40 & $\begin{array}{c}1.37 \\
(0.24)\end{array}$ & $\begin{array}{c}3.78 \\
(0.07)\end{array}$ \\
\hline $\mathrm{MORT}_{2}$ & $\begin{array}{c}-0.21 \\
(-5.19)\end{array}$ & n.s. & n.s. & n.s. & $\begin{array}{c}-0.214 \\
(-2.07)\end{array}$ & 0.51 & $\begin{array}{c}2.19 \\
(0.14)\end{array}$ & $\begin{array}{c}0.37 \\
(0.54)\end{array}$ \\
\hline $\mathrm{MORT}_{3}$ & $\begin{array}{r}-0.202 \\
(-4.75)\end{array}$ & n.s. & $\begin{array}{c}-0.37 \\
(-1.64)\end{array}$ & $\begin{array}{c}0.433 \\
(2.80)\end{array}$ & n.s. & 0.42 & $\begin{array}{c}0.44 \\
(0.51)\end{array}$ & $\begin{array}{c}2.75 \\
(0.10)\end{array}$ \\
\hline $\mathrm{MORT}_{4}$ & $\begin{array}{r}-0.096 \\
(-2.30)\end{array}$ & n.s. & $\begin{array}{l}-0.528 \\
(-2.13)\end{array}$ & $\begin{array}{r}0.514 \\
(2.83)\end{array}$ & & 0.47 & $\begin{array}{c}2.85 \\
(0.09)\end{array}$ & $\begin{array}{c}0.19 \\
(0.66)\end{array}$ \\
\hline $\mathrm{MORT}_{5}$ & $\begin{array}{l}-0.208 \\
(-6.32)\end{array}$ & n.s. & n.s. & n.s. & n.s. & 0.37 & $\begin{array}{c}2.08 \\
(0.15)\end{array}$ & $\begin{array}{l}1.85 \\
(0.17)\end{array}$ \\
\hline $\mathrm{MORT}_{6}$ & $\begin{array}{r}-0.283 \\
(-7.02)\end{array}$ & n.s. & n.s. & n.s. & n.s. & 0.42 & $\begin{array}{c}0.67 \\
(0.41)\end{array}$ & $\begin{array}{c}1.42 \\
(0.26)\end{array}$ \\
\hline $\mathrm{MORT}_{7}$ & $\begin{array}{r}-0.269 \\
(-5.85)\end{array}$ & n.s. & n.s. & n.s. & n.s. & 0.48 & $\begin{array}{c}0.01 \\
(0.98)\end{array}$ & $\begin{array}{c}2.43 \\
(0.12)\end{array}$ \\
\hline \multicolumn{9}{|c|}{ (g) Expected change in base (12-month yield spread) } \\
\hline$M O R T_{1}$ & $\begin{array}{r}-0.216 \\
(-4.80)\end{array}$ & $\begin{array}{c}0.183 \\
(1.72)\end{array}$ & n.s. & n.s. & n.s. & 0.39 & $\begin{array}{c}0.84 \\
(0.36)\end{array}$ & $\begin{array}{c}2.35 \\
(0.13)\end{array}$ \\
\hline $\mathrm{MORT}_{2}$ & $\begin{array}{l}-0.214 \\
(-5.28)\end{array}$ & n.s. & n.s. & n.s. & $\begin{array}{l}-0.135 \\
(-2.03)\end{array}$ & 0.51 & $\begin{array}{c}2.09 \\
(0.15)\end{array}$ & $\begin{array}{c}0.27 \\
(0.61)\end{array}$ \\
\hline $\mathrm{MORT}_{3}$ & $\begin{array}{r}-0.235 \\
(-6.02)\end{array}$ & $\begin{array}{c}0.214 \\
(2.06)\end{array}$ & n.s. & n.s. & n.s. & 0.41 & $\begin{array}{l}1.25 \\
(0.26)\end{array}$ & $\begin{array}{c}3.07 \\
(0.08)\end{array}$ \\
\hline $\mathrm{MORT}_{4}$ & $\begin{array}{l}-0.101 \\
(-2.40)\end{array}$ & n.s. & $\begin{array}{r}-0.412 \\
(-1.92)\end{array}$ & $\begin{array}{r}0.315 \\
(2.61)\end{array}$ & n.s. & 0.46 & $\begin{array}{c}2.27 \\
(0.13)\end{array}$ & $\begin{array}{c}0.17 \\
(0.68)\end{array}$ \\
\hline $\mathrm{MORT}_{5}$ & $\begin{array}{r}-0.208 \\
(-6.32)\end{array}$ & n.s. & n.s. & n.s. & n.s. & 0.37 & $\begin{array}{c}2.08 \\
(0.15)\end{array}$ & $\begin{array}{c}1.85 \\
(0.17)\end{array}$ \\
\hline $\mathrm{MORT}_{6}$ & $\begin{array}{l}-0.283 \\
(-7.02)\end{array}$ & n.s. & n.s. & n.s. & n.s. & 0.42 & $\begin{array}{c}0.67 \\
(0.41)\end{array}$ & $\begin{array}{c}1.42 \\
(0.26)\end{array}$ \\
\hline $\mathrm{MORT}_{7}$ & $\begin{array}{r}-0.269 \\
(-5.85)\end{array}$ & n.s. & n.s. & n.s. & n.s. & 0.48 & $\begin{array}{c}0.01 \\
(0.98)\end{array}$ & $\begin{array}{c}2.43 \\
(0.12)\end{array}$ \\
\hline
\end{tabular}

Notes: The variables $D E P_{i}$ and $M O R T_{i}$ deposit and mortgage rates for institutions $i$ respectively; n.s. indicates variable has been dropped due to insignificance; $t$-statistics in parentheses are based on Newey-West standard errors; SC is a chi-squared test for serial correlation; $H$ is a chi-squared test for heteroscedasticity ( $p$ values are in brackets). $\mathrm{N}$ indicates narrowing gap, while $\mathrm{W}$ indicates widening gap.

coefficients are correctly signed. These results provide very strong evidence in favour of our hypothesis that there is faster adjustment to gaps that are expected to widen and a lesser or no change in the adjustment speed when the gap is expected to close automatically.

It appears that the actual or expected path of future base rates are key determinants of the speed of base rate pass through. Retail rate setters appear to observe the likely future direction of change in base rates over the next twelve months before implementing changes to their own rates. The pattern of responses is consistently supportive of the theory that financial institutions respond more aggressively to widening gaps but more passively to narrowing gaps. 


\section{CONCLUSIONS}

It is a well-known feature of monetary policy operations that authorities aim to exercise control over short interest rates by adjusting the official rate, and that it is commonly assumed that there is complete transmission to short rates within a short period of time. With complete pass-through monetary policy can be more efficient in its ability to control inflation, although incomplete pass through can still be effective if it is predictable. ${ }^{23}$ Empirical models of base rate pass-through have previously tested pass-through using linear or asymmetric adjustment processes. This paper has attempted to get to grips with a wider range of potential non-linearities in adjustment of retail rates to base rates arising from menu cost models.

The initial estimates of the relationship between the level of each individual retail rate by type of product reveals complete pass-through to be the norm in the long run for deposit rates but not for mortgage rates. The non-linear forms of adjustment around these equilibria are consistent with menu cost models and may be of greater significance at low rates of interest and inflation. Endogenous and exogenous nonlinearities increase the adjustment speeds of retail rates to base rates quite dramatically when the gap between the retail rate and the base rate is widening but slowdown the adjustment when base rates are moving an a direction that will automatically close the gap. Drivers that were significant included the actual or expected change in the base rate, the expected change in the base rate proxied by the yield spread for 3, 6 and 12 month horizons.

We concluded that the main driver of base rate pass-through is the change, or expected change, to the official instrument when the gap between the base and retail rates is growing in absolute size. All individual rate series are adjusted significantly faster to close growing gaps, a result which is not observed when the gap is narrowing through the direction of change of the base rate itself. This provides some good news for monetary policy makers, since these prominent non-linearities are of a strictly limited type, and more importantly, respond to both the expected trend in rates and the aggressiveness of base rate changes.

\section{NOTES}

1. The authors are respectively, ZEI, University of Bonn and LSE; and University of Nottingham and Jean Monnet Fellow, European University Institute. This paper was written while both authors were attached to the Bank of England, but the views are not necessarily those of the Bank of England. We wish to thank Peter Andrews, Jonathan Bailey, Hasan Bakhshi, Beth Blowers, Roger Clews, Alec Chrystal, Spencer Dale, Charles Goodhart, Ben Martin, Paul Newbold, Kalin Nikolov, Chris Salmon, Dan Thornton, Tony Yates and seminar participants at the Universities of Bonn, Durham, National University of Singapore and the Bank of England for their helpful comments and suggestions.

2. Empirical assessments of the pass-through of base rate have also been conducted on market rates by Cook and Hahn (1989) and Thornton (1999) for the US and Dale (1993) for the UK. These studies show that market rates respond significantly but incompletely to changes in the official rate in the days surrounding the change, with the size of the response decreasing in the maturity of the underlying product. Cointegration analysis by Dale (1993) suggests that pass-through is complete only for very short maturities.

3. We note that Holly et al. (1999) report potential biases in estimated long run coefficients when two-step estimators are used. In practice we find little difference between the estimates using one- and two-step procedures. 
4. We recognise that a great deal of recent empirical research has shown a link between firm concentration, as a proxy for competition, and rate setting. Papers by Berger and Hannan (1989), Prager and Hannan (1998) and Kahn, Pennacchi and Sopranzetti (2002) show for deposit and lending rates that competition does have an impact on rate setting behaviour and can create asymmetries. We make the argument here that if monopolisitic competition is to be sufficient to generate discontinuous adjustment then it must ensure that the profit function levels out in theoretical models.

5. The reasoning we use is not the only motivation for why deposit or mortgage rates might be sticky. There is a growing literature on psychological and behavioural studies that can generate the same kinds of stickiness in retail rates (see Kahn, Pennacchi and Sopranzetti, 1999).

6. Although the adjustment process is quadratic and therefore puts equal weight on deviations of retail rates above and below the base rate, the presence of a positive trend in inflation generates an asymmetric response from the financial institution.

7. Time dependent (TD) rules offer explanations for co-ordinated, sychronised changes to rates as well as staggered changes, where a proportion of institutions change all their rates or all institutions change a proportion of their rates. State dependent (SD) rules create incentives to revert to a target value only when a pre-determined threshold, above or below the target, is reached, i.e. (S,s) models of Sheshinski and Weiss (1983), Caplin and Spulber (1987), Caplin and Leahy (1991). (S,s) models give reasons to believe that certain states of the economy or market competition might determine the costs of adjustment to retail rates and thus the incentive to pass rates through. Evidence from other types of price setters such as supermarkets and mail order catalogues - suggests that neither TD nor SD tells the whole story [Carlton (1986), Cecchetti (1985, 1986), Kashyap (1995)], but elements of both are pertinent. Menu costs and externalities on customers create SD because the objective is to avoid incurring the costs except when necessary, i.e. when a threshold value above or below the target is crossed. But when the state is uncertain, or needs to be learnt, and changes to prices have been frequent in the recent past, TD dominates. Here the price setter may be inclined to pause to avoid a move in the wrong direction (that must be subsequently reversed) or may avoid imposing externalities on the customer through frequent changes to prices that may in turn create costs for its own business, i.e. lost custom to competitors.

8. Bounded variables should be stationary by definition, but within a sample can appear nonstationary due to weak mean reversion or the low power of conventional unit-root tests. However, Evans and Savin (1981) show that for very persistent stationary DGPs the asymptotic unit root distribution provides a better finite sample approximation than the asymptotically correct standard normal distribution.

9. There is also a literature that uses a qualitative dependent variable approach to rate setting. Hannan and Berger (1991) and Mester and Saunders (1995) model US deposit and prime rate changes respectively using a logit model and their results are discussed below. Neumark and Sharpe (1992) use a switching model of partial adjustment for US deposit rates. The model switches according to an indicator function indicating whether the bank is below or above its long-run equilibrium mark-up, assuming long-run equilibrium deposit rates to be proportional to Treasury Bill rates (we note that this runs counter to the observed behaviour of margins which preserves the markup in percentage points, see footnote 20 below).

10. The heaviside indicator creates a switching variable from continuous data by defining a variable with a value equal to one when the continuous variable is less than some threshold value, and zero otherwise. That is $I=1$ if $x_{t}<X$, where $X$ is the threshold, and 0 otherwise.

11. The non-linear ECM has been estimated in one step using maximum likelihood, Frost and Bowden (1999) and Neumark and Sharp (1992). The two-step model has been used previously for different problems by Scholnick (1996) and Ericsson, Hendry and Prestwich (1998). We recognise that asymmetry may bias the estimates of the long-run intercept when two-step estimators are employed (c.f. Holly et al. (1999)), we therefore estimated our non-linear models using both a two step and a one-step (NLLS) estimator. Our results showed no evidence of bias.

12. The standard variable rate (SVR) is a term adopted by the retail banks which typically refers to the reference rate against which they describe their other mortgage products, e.g. a mortgage rate is offered at a discounted rate of $0.5 \%$ below SVR, returning to SVR after a given period. Across the market less than $40 \%$ of mortgage stock is at this rate, down from $50 \%$ in early 1999 . Until the 1990 s almost all mortgages were charged at SVR, but following the increase in mortgage rates to 15 percentage points in 1989 and the experience of Black Wednesday, an increasing proportion of mortgage products have fixed rates.

13. These are discussed by Gallagher and Milne (1997) in relation to UK mortgage margins and include cashbacks (cash payments to eligible new borrowers), interest rate discounts, free 
home and contents insurance. They are thought to have had an active role in the remortgage market in the last few years. Their calculations suggested that 'cashbacks would have reduced spreads by between 9 and 13 basis points' (p. 39), but these would not have substantially altered the modest reduction in retail rates offered by building societies. Deposit rates have also been influenced by the provision of new services such as cashback, switch facilities, and telephone banking that augment the competitiveness of a retail product on non-price grounds.

14. Centred impulse dummies do not affect the asymptotic distribution of the test statistics, so that the standard critical values are valid. The dummies included control for large outliers which can be explained by the ERM crisis in 1992/93 and a change in the composite tax rate in 1986. The outlier in 1988:8 was caused by a large jump in the base rate. Despite the inclusion of these dummies the null of normality is still rejected at the one percent level in each case. But that does not invalidate our test results, since the Johansen procedure does not strictly depend on the normality assumption (Lütkepohl, 1991).

15. We refer the reader to Johansen (1995) and Boswijk (1995) where the implications of weak exogeneity on the conditional/marginal structure is explained. In short, a weakly exogenous process excludes the long-run relationship and any conditional model of the remaining endogenous variables is sufficient to recover information about the parameters of interest. Johansen's test of the weak-exogeneity proposition is used to confirm the validity of this partition, so that neglect of the marginal model for the base rate does not result a loss of information.

16. Interestingly, the margins on deposits and mortgages as a percentage of the base rate are countercyclical with the base rate itself. This suggests that it is the percentage point margin that banks and building societies preserve not the percentage relative to the base rate; this policy generates the rise in the percentage margin as base rates fall and vice versa. As banks and building societies care about the real margin, it seems logical that the margin is additive rather than multiplicative.

17. In a multivariate framework pass-through can be analysed by simulating the impulseresponse of retail rates to an innovation to the base rate. The problem is that for each system we will obtain a different set of base rate shocks and a different endogenous response of the base rate. This makes it impossible to draw valid conclusions on the responsiveness of retail rates per se and on differences in pass-through across institutions. Moreover, it would not be possible to give any clear interpretation of the economic meaning of the innovations to the base rates. Since we have shown that base rates are weakly exogenous we avoid these problems and analyse base rate pass-through based on linear and non-linear errorcorrection models.

18. We note that there is also a theoretical inconsistency between linear ECMs and the menu cost model that we have used to motivate our study. A linear model with its assumption of convex costs of adjustment is unable to capture the occasional step changes in rates, but a non-linear model has no such difficulty.

19. We introduced non-linearities into the short-run dynamics both before and after allowing for non-linearities in $\gamma$, but the results were not influential.

20. Although with credible inflation (forecast) targeting the market may take the view that inflation and interest rates will return to normal in the long run.

21. We recognise that our statements in this paragraph imply a narrow view of the expectations theory of the term-structure of interest rates since we assume forecasts of short term rates are stationary, and do not contain risk premia. We also assume that the movements in the yield spread reflect expectations of future inflation rather than the business cycle and expectations of policy changes.

22. While we use the spread between the three-month LIBOR and base rate, there are many other available measures of expected inflation. Two measures of expected inflation up to one year ahead indicate market expectation of future changes to official rates in the next twelve months. These can be derived from (i) the Gallup survey on expected inflation; and (ii) expected inflation measured over one year by the difference between real and nominal gilt yield curves. Each has its drawbacks as a measure of expected inflation. The first series is too smooth and lags behind the actual rate. The latter is difficult to implement in practice because the Svensson yield curves, Svensson (1994, 1995), constructed as an extrapolated curve over the whole maturity spectrum, rely on data for real and nominal gilt curves that is often patchy. At the short end of the spectrum this can be a particular problem due to the small number of gilts traded and the curvature of the yield curve. The spline-based method of Waggoner (1997) might be a solution - but again this can only be calculated for regions where the data exist - and thus it suffers from the same basic problem as the Svensson curves.

23. The effectiveness of monetary policy will depend on the real effects of real short rates, not just the degree of pass-through. It will also operate through many channels. The pass- 
through from the repo rate to retail rates is not the only channel by which monetary policy can operate, and therefore the point being made here is that the degree of effectiveness of monetary policy is influenced through the retail rate channel.

\section{REFERENCES}

Akerlof, G. and Yellen, J. (1985). A near-rational model of business cycles with wage and price inertia. Quarterly Journal of Economics, 100, 823-38.

Athukorala, P. and Menon, J. (1994). Exchange rates and strategic pricing in Swedish manufacturing exports. Oxford Bulletin of Economics and Statistic, 57 (4), 529-42.

Ball, L. and Mankiw, N. G. (1994). Asymmetric price adjustment and economic fluctuations. Economic Journal, 104, 247-61.

BALl, L. and Romer, D. (1989). Real rigidities and the non-neutrality of money. Review of Economic Studies, 57, 183-203.

Berger, A. N. and HANnAN, T. H. (1989). The price-concentration relationship in banking. Review of Economics and Statistics, 71, 291-9.

Blanchard, O. J. and Fischer, S. (1989). Lectures in Macroeconomics. MIT Press, Cambridge.

Borio, C. E. V. and Fritz, W. (1995). The response of short-term bank lending rates to policy rates: a cross-country perspective. BIS working paper No. 27.

Borio, C. E. V. (1997). The implementation of monetary policy in industrialised countries: a survey. BIS Economic Papers, 47, July.

BoswiJk, H. P. (1995). Efficient inference on cointegration parameters in structural error correction models. Journal of Econometrics, 69, 133-58.

CAPlin, A. and LeAhy, J. (1991). State dependent pricing and the dynamics of money and output. Quarterly Journal of Economics, 106, 683-708.

CAPlin, A. and Spulber, D. (1987). Menu costs and the neutrality of money. Quarterly Journal of Economics, 102, 703-25.

Carlton, D. W. (1986). The rigidity of prices. American Economic Review, 76, 637-58.

CECChetTi, S. (1985). Staggered contracts and the frequency of price changes. Quarterly Journal of Economics, 100, 935-59.

CECChetti, S. (1986). The frequency of price adjustment. Journal of Econometrics, 31, 255-74.

COOK, T. and HAHN, T. (1989). Effects of changes in the federal funds rate target on market interest rates in the 1970s. Journal of Monetary Economics, 24, 331-51.

DALE, S. (1993). Effects of changes in official UK rates on upon market rates since 1987. Manchester School, 61 (Supplement), 76-94.

DixiT, A. (1989). Hysteresis, import penetration, and exchange rate pass-through. Quarterly Journal of Economics, 104 (2), 205-228.

Dornbusch, R. (1987). Exchange rates and prices. American Economic Review, March.

Enders, W. and Granger, C. W. J. (1998). Unit roots and asymmetric adjustment with an example using the term structure of interest rates. Journal of Business and Economic Statistics, 16 (3), 304-11.

Ericsson, N. R., Hendry, D. F. and Prestwich, K. M. (1998). The demand for money in the UK 1878-1993. Scandanavian Journal of Economics, 100, 289-324.

Evans, G. and Savin, N. (1981). Testing for unit roots: 1. Econometrica, 49, 753-779.

Feenstra, R., Gagnon, J. and Knetter, M. (1996). Market share and exchange rate pass through in world automobile trade. Journal of International Economics, 40 (1-2), 187-208.

Froot, K. A. and Klemperer, P. (1989). Exchange rate pass-through when market share matters. American Economic Review, 79, 637-54.

Frost, D. and Bowden, R. (1999). An asymmetry generator for error-correction mechanisms, with application to bank mortgage-rate dynamics. Journal of Business and Economic Statistics, 17, 253-63.

Gallagher, N. and Milne, A. (1997). UK mortgage margins. Bank of England Financial Stability Review, November 1997, 38-46.

Goodfriend, M. (1991). Interest rates and the conduct of monetary policy. Carnegie Rochester Series on Public Policy, 34, 7-30.

Goodhart, C. A. E. (1996). Why do monetary authorities smooth interest rates? LSE FMG Special Paper No. 81.

(C) The London School of Economics and Political Science 2004 
GRANGER, C. W. J. and LEE, T. H. (1989). Investigation of production, sales and inventory relationships using multicointegration and non-symmetric error correction models. Journal of Applied Econometrics, 4, S145-59.

HANNAN, T. H. and BERGER, A. (1991). The rigidity of prices: Evidence from the banking industry. American Economic Review, 81, 938-45.

HeFFERnAN, S. (1997). Modelling British interest rate adjustment: an error-correction approach. Economica, 64, 211-231.

Holly, S., Turner, P. and Weeks, M. (1999). Asymmetric adjustment and bias in cointegrating vectors. University of Sheffield, mimeo.

JOHANSEN, S. (1995). Likelihood-Based Inference in Cointegrated Vector AutoRegressive Models. Oxford University Press, Oxford.

Kahn, C., Pennacchi, G. and Sopranzetti, B. (1999). Bank deposit rate clustering: theory and empirical evidence. Journal of Finance, 54, 2185-2214.

Kahn, C., Pennacchi, G. and Sopranzetti, B. (2002). Bank consolidation and consumer loan interest rates. University of Illinois, mimeo.

KASHYAP, A. S. (1995). Sticky prices: new evidence from retail catalogs. Quarterly Journal of Economics, 110, 247-74.

Krugman, P. R. (1987). Pricing to market when exchange rate changes. in Financial Linkages Among Open Economies. MIT Press, Cambridge MA.

LütKePOHL, H. (1991). Introduction to Multiple Time Series Analysis. Springer-Verlag, New York.

MANN, C. (1986). Prices, profit margins and exchange rates. Federal Reserve Bulletin, 72 (6), 366-79.

Mankiw, N. G. (1985). Small menu costs and large business cycles: a macroeconomic model. Quarterly Journal of Economics, 100, 529-37.

Marston, R. C. (1990). Pricing to market in Japanese manufacturing. Journal of International Economics, 29 (3-4), 217-34.

Mester, L. and SAunders, A. (1995). When does the prime rate change? Journal of Banking and Finance, 19, 743-64.

MishKin, F. S. (1990a). Information in the longer maturity term structure about future inflation. Quarterly Journal of Economics, 105, 815-28.

Mishkin, F. S. (1990b). A multicountry study of the information in the shorter maturity term structure about future inflation. Journal of International Money and Finance, 10, 2-22.

MishKin, F. S. (1991). What does the term structure tell us about future inflation. Journal of Monetary Economics, 25, 77-95.

Neumark, D. and Sharpe, S. (1992). Market structure and the nature of price rigidity: evidence from the market for consumer deposits. Quarterly Journal of Economics, 107, 657-80.

PAISLEY, J. (1994). A model of building society interest rate setting. Bank of England Working Paper, No 22.

Prager, R. A. and Hannan, T. H. (1998). Do substantial horizontal mergers generate significant price effects? Evidence from the banking industry. Journal of Industrial Economics, 46, 433-52.

Rotemberg, J. (1992). Monopolistic price adjustment and aggregate output. Review of Economics and Statistics, 49, 517-31.

SACK, B. (1998). Does the Fed work gradually? A VAR analysis. Federal Reserve Board of Governors, FEDS Working Paper No. 17.

SCHOLNick, B. (1996). Asymmetric adjustment of commercial bank interest rates: evidence from Malaysia and Singapore. Journal of International Money and Finance, 15, 485-496.

SHESHINSKI, E. and WeIsS, Y. (1983). Optimum pricing policy under stochastic inflation. Review of Economics and Statistics, 50, 513-29.

SvensSON, L. E. O. (1994). Estimating and interpreting forward interest rates: Sweden 1992-94. IMF Working Paper No. 114.

Svensson, L. E. O. (1995). Estimating forward rates with the extended Nelson and Siegel method. Sveriges Riksbank Quarterly Review, 1995, 3-13.

Thornton, D. L. (1999). The Fed's influence on the Federal Funds rate: Is it open market or open mouth operations? Paper presented at the Money, Macro and Finance Research Group, September 1999.

WAGGONER, D. (1997). Spline methods for extracting interest rate curves from coupon bond prices. Federal Reserve Bank of Atlanta Working Paper No. 97-10. 